Volume 13

Issue 2 Rethinking Genocide, Mass Atrocities,

and Political Violence in Africa: New Directions,

Article 8

New Inquiries, and Global Perspectives

6-2019

\title{
The Practice, Pitfalls, and Prospects of the Responsibility to Protect in Africa
}

Nicholas I. Erameh

University of Ibadan

Follow this and additional works at: https://digitalcommons.usf.edu/gsp

\section{Recommended Citation}

Erameh, Nicholas I. (2019) "The Practice, Pitfalls, and Prospects of the Responsibility to Protect in Africa," Genocide Studies and Prevention: An International Journal: Vol. 13: Iss. 2: 58-73.

DOI:

https://doi.org/10.5038/1911-9933.13.2.1703

Available at: https://digitalcommons.usf.edu/gsp/vol13/iss2/8

This Articles is brought to you for free and open access by the Open Access Journals at Digital Commons @ University of South Florida. It has been accepted for inclusion in Genocide Studies and Prevention: An International Journal by an authorized editor of Digital Commons @ University of South Florida. For more information, please contact digitalcommons@usf.edu. 


\title{
The Practice, Pitfalls, and Prospects of the Responsibility to Protect in Africa
}

\author{
Nicholas Idris Erameh \\ University of Ibadan \\ Ibadan, Oyo State, Nigeria
}

\section{Introduction}

Scholars have argued there is increasing concern from the international community concerning its response to various humanitarian catastrophes that threaten humanity. ${ }^{1}$ Yet, violent conflicts in developing countries and, particularly in Africa have led to the death of thousands of civilians. Nearly 600,000 civilians in twenty-seven African countries have been massacred in the past two decades, while tens of millions more have been displaced, killed in battles, or perished from the indirect causes of such attacks and armed conflicts. ${ }^{2}$ It is within this context that the Responsibility to Protect (RtoP) resonated as a necessary framework to respond to the problematic challenges of the twenty-first century. However, just like its forerunners, RtoP has generated much debate among states, policymakers, and even International Relations scholars.

On one hand, scholars such as Teson, Wheeler, Weiss, Arbour, Bellamy and Luck, ${ }^{3}$ have declared support for RtoP, as a moral framework, to respond to humanitarian catastrophes. On the other hand, scholars such as Mandani, Chandler, Branch, and Wai ${ }^{4}$ view RtoP with great suspicion, while submitting the doctrine seeks to bypass state sovereignty in justification of humanitarian intervention.

Since its adoption, RtoP has been applied in Kenya, South Sudan, Libya, Mali, and Cote d'Ivoire, as well as in other ongoing cases. While the doctrine remains largely contested, the nature of conflict with grave consequences for humanity justifies the continuous application of the doctrine. However, the practice of the RtoP doctrine has not escaped seemingly persistent questions of who, why, when, and how interventions should be carried out in the affairs of another state by a state or group of states. This article seeks to explore the glaring and inescapable challenges associated with the doctrine within the ambits of the use of force as articulated in Pillar three of RtoP. It interrogates those cases where RtoP has been invoked in Africa, the emerging challenges of those interventions on the humanitarian intervention discourse, and the future of the RtoP doctrine. It is argued that the use of military force to protect civilians in conflict situation remains shrouded in controversy and unpredictable consequences. This is evident in the way and manner the Libyan, Mali and Cote d'Ivoire interventions played out. In essence, these interventions lead to the death of more lives than expected, which contradicts the fundamental argument used to justify many interventions: to protect civilian life.

Notably, the Libyan debacle only serves to underscore how the NATO led intervention was not only used as a fig leaf for Western powers, but also led to greater violations of human rights as well as the death of thousands of civilians. ${ }^{5}$ While it may seem the reviewed cases of the RtoP in Africa have generated a series of criticisms, the need to protect civilians remains persistently compelling. Hence, it is critical to monitor future interventions to ameliorate the operational challenges associated with their practice, emphasize the role of local dynamics when contemplating interventions, as well as consider the power relations between interveners and those intervened upon before authorizing intervention under the auspice of the RtoP doctrine. More importantly, efforts should be geared towards soft power diplomacy such as preventive diplomacy, negotiations, initiating and supporting peace agreements, and greater investment channeled into building peace through infrastructural development.

\section{Theoretical Considerations}

The protection of civilians and civilian populations in armed conflict remains a cornerstone of International Humanitarian Law (IHL). Among other roles, IHL seeks to set and monitor the expected duties, obligations or rules of engagements that guide parties to a conflict. Though early experiences of war assumed an interstate dimension, the period after the cold war witnessed a flourishing of intrastate conflict, which had a significant impact on the civilian populations. Since

${ }^{5}$ Douglas Irvin-Erickson, "Protection from Whom? Tensions, Contradictions, and Potential in the Responsibility to

Protect," in Rethinking Security in the Twenty-First Century, ed. Edwin Daniel Jacobs (London: Palgrave, 2016), 106. 
then, the international community has engaged in different forms of activities aimed at protecting civilian populations. In practice, this has included the wide range of consensual and nonconsensual activities embarked upon by the international community to protect civilians outside the contexts of armed conflict. ${ }^{6}$ Within this context, Williams lists five reasons why the need to protect civilians remains vital in Africa. ${ }^{7}$ First, the wider implications in terms of human cost as a result of armed conflicts; second, the consistent nature of various United Nations Security Council resolutions to protect civilians in armed conflict situations; third, the understanding that failed or collapsed peace deals greatly impact governance structures; fourth, the necessity to protect civilians from atrocity crimes as stipulated in the RtoP doctrine; and fifth, the belief that civilian protection remains a sine qua non to addressing the security and development challenges facing Africa. Undoubtedly, these persistent and protracted conflicts witnessed in and around Africa provoke both local and international concerns. It is within this context the global RtoP doctrine resonated. Since its adoption, however, the doctrine has been confronted with a series of criticisms and counter criticisms.

For instance, in separate studies, Alex Bellamy sought to explore the context of its adoption, the intricacies surrounding the doctrine, and its positive or negative impact on the instutionalization of the RtoP doctrine five years after its establishment. ${ }^{8}$ For Bellamy, while the doctrine has been successfully applied by the various United Nations Security Council resolutions, RtoP remains enmeshed in conceptual ambiguity and abuse. Though these interventions have led to moral hazards, evidence abound suggests the doctrine remains vital for the prevention of atrocity crimes in conflict situations. Similarly, Gareth Evans draws our attention to what he considers as attacks on the RtoP due to misconception and misinformation. In particular, Evans frowns upon narrow comparisons between RtoP and humanitarian intervention. While humanitarian intervention emphasizes the use of force, for Evans, RtoP promotes a wide range of activities aimed at civilian protection, and force should always be considered as a last option. Moreover, for Evans RtoP marks a conceptual victory in the protection discourse in and around Africa. ${ }^{9}$ Elsewhere, Tim Murithi pays critical attention to the emergence of RtoP and the extent to which the African Union (AU) - through its Constitutive Act - has sought to complement the R2P doctrine. Murithi notes that the expanding gatekeeping role played by the AU in a series of RtoP interventions in such places as Burundi, Darfur, and Somalia, and points to the fact that the AU is committed to global peace. Despite this commitment, the AU seems to be confronted with both operational and institutional challenges, which have hampered its quest for peace throughout the continent. Therefore, to bolster RtoP, there is an urgent need for Africa leaders to reorient themselves toward their understanding of the doctrine, their disposition to conflict, and conceptualizing new avenues to address armed conflict. ${ }^{10}$

There is little doubt these emergent challenges and the need to protect civilians from violence opens a new chapter in the humanitarian discourse in and around Africa. To that end, Martha Finnemore has examined the changes over why Western countries continue to devote resources to conflicts in Africa, and the causes, nature, and consequences of these conflicts. Finemmore concludes humanitarian intervention is not a new phenomenon in Africa. Rather, what seems confusing and controversial is the perception of the justification for the use of force for the

\footnotetext{
${ }^{6}$ Cristina C. Carmen, "Protecting Civilians in Armed Conflict: International Framework and Challenges," European Parliamentary Research Service (EPRS) Briefing, 2016, 2, accessed January 12, 2017, Http//www.europa.eu/thinktank/en/ document.html?reference=EPRS_BRI(2016)573917.

${ }^{7}$ Williams, Enhancing Civilian Protection, 5-6.

${ }^{8}$ Bellamy, Five Years On, 166; Alex J. Bellamy, Global Politics and the Responsibility to Protect: from Words to Deeds (Abingdon: Routledge, 2011), 24.

${ }^{9}$ Gareth Evans, "Implementing the Responsibility to Protect: Lessons and Challenges," (Alice Tay Lecture on Law and Human Rights, Australian National University, Canberra, Australia, May 5, 2011), accessed January 12, 2017, http:// www.gevans.org/speeches/speech437.html.

${ }^{10}$ Tim Murithi, "The Responsibility to Protect, as Enshrined in Article 4 of the Constitutive Act of the African Union," African Security Review 16, no. 3 (September 2007), 20-24.
} 
purpose of civilian protection. ${ }^{11}$ For Anne Orford, scholars, experts, and practitioners who throw their weight behind liberal Western interventionism ignore the imperial motives of such external interventions. This has been made worse by the false understanding among Western nations of the potency of international institutions and the ability of human rights advocacy groups to rally around the victims of atrocity crimes. Orford concludes these interventions, regardless of how they are conceived, remain shrouded in the long running adventurism of Western nations in relation to power and politics. ${ }^{12}$

Focusing on the RtoP intervention in Libya, Mathias Dembinski and Theresa Reinold observe how the RtoP intervention has led to mixed reactions. First, criticisms against the AU for its inability to adopt a proactive stance towards the Libyan conflict in the face of glaring and continuous atrocity crimes against the civilian population. On the other hand, the apparent misunderstanding and subsequent misinterpretation of the United Nations Security Council Resolution 1973 by NATO not only led to the killings of more civilians, but also the eventual ousting and death of Ghaddaffi. Undoubtedly, the inability of the international community to effectively monitor the Resolution 1970 before pronouncing Resolution 1973 has raised some suspicions about liberal western interventionism..$^{13}$ Thus, for them, the Libyan intervention raised a critical challenge of who should be saddled with the responsibility of carrying the burden of civilian protection in conflict situations. While this question remains unresolved, African nations will continue to raise their suspicion about the practice and objective of RtoP, particularly when it is executed by a coalition of willing (Western) states. This, for them, has the potential to undermine both the global consensus surrounding the RtoP doctrine and its chances for future use. ${ }^{14}$

Drawing from the Libyan experience, Roland Paris itemizes some of the consequences of the intervention into what he refers to as five structural problems: Mixed motives, counter factualness, conspicuous harm, end state crisis, and the problem of inconsistency. Mixed motive problems: Though the sole aim of humanitarian intervention is to save lives, various cases have suggested otherwise. Military intervention in armed conflict situations has been conducted based on economic and geopolitics calculations and these calculations are premised on the grounds that the very idea of establishing RtoP resonates largely around self-interest. The Counterfactual Problem: One of the difficulties in civilian protection is the puzzle of measuring the extent to which an intervention can be judged successful. When compared to other types of military engagement or operations and, particularly those carried out with the aim to capture territories, defeat or disarm opposing forces, and counterinsurgency, the chances of success of humanitarian intervention remains relatively low (Paris 2014). The Conspicuous Harm Problem: In this case, it has become increasingly clear that no matter how well planned, military operations are associated with collateral damage. Though associated with many military operations this harm is felt more with military operations that base their legality on the strict belief of preventing harm (Paris 2014). Such was the case with the NATO intervention in Libya. The indiscriminate aerial bombardment of Libya led to the death of civilians. The End State Problem: Noble as the intention of intervening countries may be, ensuring that civilians in protected areas remain safe withdrawal has often been a problem in conflict zones. On the other, the issue of persistent political instability, lack of coordination, and relapsing into conflict in the state intervened upon and neighboring states remain additional issues of the end state problem. Problem of Inconsistency: Intervening in conflict situations has been largely inconsistent, and at most times depends on the interests of intervening states. The problem of balancing moral authority and adhering to the procedures of intervention has further increased the tension of

\footnotetext{
${ }^{11}$ Martha Finnemore, The Purpose of Intervention: Changing Beliefs About the Use of Force (Ithaca: Cornell University Press, 2003), 134-135.

${ }^{12}$ Orford, Reading Humanitarian Intervention, 20.

${ }^{13}$ Spencer Zifcak, "The Responsibility to Protect After Libya and Syria," Melbourne Journal of International Law 13, no. 1 (2012), 8; Mohammed Nauruzzmaan, "The 'Responsibility to Protect Doctrine: Retrieved in Libya, Buried in Syria," Insight Turkey 15, no. 2 (2013), 63; Murithi, Enshrined in Article 4, 20-24.

${ }^{14}$ Matthias Dembinski and Theresa Reinold, "Libya and the Future of the Responsibility to Protect - African and European Perspectives," PRIF report, no. 107 (Frankfurt: Peace Research Institute Frankfurt, 2011), 24, accessed January 18, 2019, https://www.hsfk.de/fileadmin/HSFK/hsfk downloads/prif107.pdf.
} 
inconsistency. Though inaction in the face of atrocity crimes discredits RtoP, the indiscriminate use of military force underscores the seeming inconsistency in responses to armed conflict. For Paris, the emergence of the aforementioned problems in the Libyan intervention further deepened the negatively perceived push for liberal Western interventionism, sovereignty, and the human rights protection dilemma. Hence, the application and consequent failure of RtoP in this case point to the fundamental flaws that remain with the doctrine and its expected benefits. As such, rather than the failures of the RtoP addressing future interventions, Paris concludes that such cases will only serve to expose RtoP..$^{15}$ Furthermore, some critical scholars have focused more on the proliferation of interventions in Africa and their consequences for the continent and global security. Zubarui Wai remains prominent among this set of scholars. For Way, though interventions in Africa qualify the just cause criteria, the way and manner the RtoP doctrine has been used differs sharply from what the doctrine was actually fashioned to address. This argument is premised on the outcomes of both the Libyan and the Mali intervention respectively. Thus, noble as the intentions of the intervening countries may have been, the main idea behind this humanitarian upsurge remains nothing but economic imperialism clothed in humanitarian intentions. Moreover the global war on terror has equally provided a golden opportunity for Western imperialists to advance their economic pursuits violently. Wai concludes that more worrisome is the fact that apart from the Libyan and Mali interventions, Cote d'Ivoire, Central African Republic have the trappings of Western adventurism as a disguise for human rights protection. ${ }^{16}$

On the contrary, counter restrictionists, experts, and advocates of the RtoP doctrine have argued that the Libyan intervention marks a defining moment for the doctrine. Though the use of force, as experienced in Libya was not generally consisted with the pronouncements of the United Nations Security Council, the international community needs to make sure that whenever interventions are authorized, it must strictly focus strictly on civilian protection. ${ }^{17}$ Consequently, by reassessing the interventions in Libya and Côte d'Ivoire, Thakur argues RtoP underscores the need to balance state sovereignty and human rights protection, the dilemma between interests and values, as well as striking a balance between unilateral interferences and instutionalized indifference in conflict situations. He concludes that the RtoP doctrine remains beneficial to intervening states as well as those intervened upon. The doctrine comes with assurances of due process, which stipulates how, when, and who should carry out interventions for civilian protection. ${ }^{18}$ On a similar note, Francesco Francioni and Christine Bakker argue the international intervention in Libya and Mali implies Western countries have demonstrated their preparedness to avoid the mistakes of Rwanda. This, for them, is further demonstrated in the leadership position the United States has assumed in these interventions. ${ }^{19}$ Though Western countries have been at the forefront of the propagation of RtoP, many African countries have continued to throw their weight behind the doctrine. Therefore, in drumming up support for the doctrine, Jeremy Sarkin ${ }^{20}$ examines the milestones that have been achieved and the extent to which R2P has received wide or mass support. For Sarkin, while human rights violations persist, sovereignty and issues of non-interference remain a stumbling block to addressing this dilemma. However, the ugly events witnessed in the nineteenth and twentieth centuries suggested the need for a framework for the protection of civilians. Such led to the process and final adoption of the RtoP doctrine, which was expected to put the duty of protection at the door steps of the states and the inevitably of the international community to intervene should

\footnotetext{
${ }^{15}$ Roland Paris, "The 'Responsibility to Protect' and the Structural Problems of Preventive Humanitarian Intervention," International Peacekeeping 21, no. 5 (October 2014), 572- 578.

${ }^{16}$ Wai, The Empire's New Clothes, 494- 495.

${ }^{17}$ Ramesh Thakur, "Libya and the Responsibility to Protect: Between Opportunistic Humanitarianism and Value-Free Pragmatism," Security Challenges 7, no. 4 (2011), 24- 25.

${ }^{18}$ Ibid.

${ }^{19}$ Francesco Francioni and Christine Bakker, "Responsibility to Protect, Humanitarian Intervention and Human Rights: Lessons from Libya to Mali," Transworld, Working paper no. 15 (April 2013), accessed January 18, 2019, http://www. iai.it/sites/default/files/TW WP 15.pdf.

${ }^{20}$ Jeremy Sarkin, "The Responsibility to Protect and Humanitarian Intervention in Africa," Global Responsibility to Protect 2, no. 4 (2010), 387.
} 
states fail. The major problem of the RtoP is that, as compared to other international frameworks that are situated within the ambits of international law, the doctrine remains a norm. This has made to the doctrine vulnerable to diverse interpretations, criticisms and counter criticisms.

\section{Historicizing RtoP and its Practice in Africa}

Building on Francis Deng and colleagues' thesis on sovereignty as responsibility, and the shameless inaction of the international community in the Kosovo and Rwanda, Kofi Annan, former UN Secretary-General, challenged world leaders on the need for proactive steps concerning the protection of civilians. The ideal RtoP would be of great importance to the international community, as a human rights framework, was first articulated by Kofi Annan. He believed RtoP had the potential to resolve the broader justice and human rights protection conundrum. For Anna, this objective had merit over his earlier thought of creating consensus around state sovereignty and individual sovereignty.22 Precisely, RtoP challenges the normative Westphalia approach to sovereignty by attempting to reconceptualize sovereignty from being a right of states to a responsibility of states. Conceived as such, this responsibility can be withdrawn from the moment a state reneges on its obligation to protect its citizens. Furthermore, the doctrine empowers the international community to sideline state sovereignty in a bid to protect civilian populations from war crimes, ethnic cleansing, genocide, and crimes against humanity. This might also include the use of military force if need be. ${ }^{23}$ After much deliberation, parley, consultation, and consideration among world leaders and practitioners, experts, and concerned states, the International Commission for Intervention and State Sovereignty (ICISS) released a report in 2001 on RtoP. The report aimed to redirect the focus on intervention from a "right to intervene" to "a responsibility" and a new understanding of sovereignty. Central to RtoP is the manifest role of states in the protection of its citizens from war crimes, genocide, ethnic cleansing crime against humanity, and the international community's role should a state fail. Accordingly, the ICISS identified three fundamental components of the RtoP doctrine: responsibility to prevent, responsibility to react, and the responsibility to rebuild.

A. The responsibility to prevent: Within this component, the doctrine stipulates that to address both the root causes and direct causes of internal conflict and other man-made crises putting populations at risk, preventive measures must be put in place.

B. The responsibility to react: In violent situations, there must be an adequate response in situations of compelling human need with appropriate measures, which may include coercive measures like sanctions and international prosecution, and in extreme cases military intervention.

C. The responsibility to rebuild: RtoP equally emphasized the need for post-engagement obligations, and these may include full assistance with recovery, reconstruction, and reconciliation, and addressing the causes of the harm the intervention was designed to halt or avert. $^{24}$

\footnotetext{
${ }^{21}$ Francis M. Deng, Sadikel Kimaro, Terrence Lyons, Donald Rothchild, and I. William Zartman. eds., Sovereignty as Responsibility: Conflict Management in Africa (Washington, DC: Brookings Institution Press, 2010), 33.

${ }^{22}$ Gareth Evans, "From Humanitarian Intervention to Responsibility to Protect" Wisconsin International Law Journal 24, no. 3 (2006), 708- 709.

${ }^{23}$ Alan J. Kuperman, "Rethinking the Responsibility to Protect," The Whitehead Journal of Diplomacy and International Relations 33, no. 4 (2009), 19.

${ }^{24}$ Greg Puley, "The Responsibility to Protect: East, West, and Southern African Perspectives on Preventing and Responding to Humanitarian Crises," Working paper no. 05-5 (Ontario: Africa Peace Forum, African Women's Development and Communication Network, Africa Institute of South Africa, and Project Ploughshares, 2005), 12, accessed January 18, 2019, http://www.responsibilitytoprotect.org/files/ploughshares.pdf.
} 
Furthermore, the ICISS listed some precautions or conditions that must be met before contemplating intervention in a conflict situation. ${ }^{25}$ This included: just cause, right intention, proportional means, reasonable prospects and last resort.

$\checkmark$ Just Cause: Intervention can be justified when there is an immediate or actual threat to civilians, and this includes killing, forcible expulsion, acts of terror, large scale violation of rights.

$\checkmark$ Right intention: The primary purpose of the intervention must be to halt or avert human suffering.

$\checkmark$ Proportional means: Within principle, the scale, duration, and intensity of the planned military intervention should be at best the minimum required to secure the defined human protection objective.

$\checkmark$ Reasonable prospects: Whenever interventions are contemplated, there must be a reasonable chance of success in halting or averting the suffering that with which the consequences of action is not likely to be worse than the consequences of inaction.

$\checkmark$ Last resort: The use of military force is only justifiable when it is apparent that other non-military options for the mediation, prevention, or peaceful resolution of the crisis have been explored.

Since RtoP was adopted, there have been a series of attempts to institutionalize the doctrine at the international, regional, and sub-regional levels respectively. Unlike humanitarian intervention, Ramesh Thakur posits the ICISS argued RtoP would put the needs and interests of the victims of atrocities ahead of intervening powers. ${ }^{26}$ It is a victim and people centered, while humanitarian intervention privileges the perspectives, preferences, and priorities of the intervening states. Since the initiation of the doctrine, it has generated a heated debate among scholars and practitioners. For scholars such as Evans and Bellamy, the RtoP doctrine is not only timely, but it also goes a long way in addressing the long-standing problem of humanitarian catastrophes. ${ }^{27}$ While for others, including Mandani, Branch, and Kuperman, the RtoP doctrne negates the norm of nonintervention, the prohibition on the use of force, and RtoP plainly remains nothing but a smoke screen for Western imperialism disguised by a humanitarian pretext. ${ }^{28}$ While other have argued that in spite of the challenges of RtoP, the doctrine is here to stay. ${ }^{29}$

\section{Libya and the 2011 Uprising}

The Arab spring that led to a series of protest in Tunisia, Egypt, Yemen, and Bahrain amongst others, spread to Libya on February 15, 2011. On February 16, 2011 a group of lawyers staged a peaceful protest in the front of the North Benghazi Court calling for political and democratic reforms. Following the initial, minor, and peaceful protest against the Ghaddaffi regime, a violent crowd set ablaze three police stations, the headquarters of the internal security force, and the public attorney's office. In the cities of Al- Baida and Benghazi, police stations and security headquarters

${ }^{25}$ Gareth Evans and Mohammed Sahnoun, “The Responsibility to Protect," Foreign Affairs 81, no. 6 (Nov - Dec 2002), 99110. DOI: $10.2307 / 20033347$

${ }^{26}$ Ramesh Thakur, "Emerging Powers and the Responsibility to Protect after Libya," NUPI, Policy Brief no. 15 (Oslo: Norwegian Institute of International Affairs, January 2012), 1- 4, accessed December 18, 2018, https://brage.bibsys.no/ xmlui/handle/11250/224065.

${ }^{27}$ Gareth Evans, “The Responsibility to Protect: An Idea Whose Time Has Come and Gone?," International Relations 22, no. 3 (2008), 285; Bellamy, Five Years On, 143- 144.

${ }^{28}$ Mamdani, Saviors and Survivors, 25-29; Adam Branch, Irresponsibility, 109; Alan J. Kuperman, "False Pretense for War in Libya?", The Boston Globe, April 14, 2011, accessed January 12, 2017, http://www.boston.com/bostonglobe/editorial opinion/opedi/articles/2011/04/14/false pretense for war in libya.

${ }^{29}$ Gareth Evans, “The Consequences of Syria: Does the Responsibility to Protect Have a Future?," E- International Relations, 2014, accessed January 18, 2019, https://www.e-ir.info/2014/01/27/the-consequences-of-non-intervention-in-syria-doesthe-responsibility-to-protect-have-a-future/. 
were also attacked. ${ }^{30}$ Thereafter, a series of protests continued, calling for the resignation of Ghaddaffi, and began to take on a violent dimension. A furious Ghaddaffi showed no sign of giving into the activities of the protesting civilians. Instead, he ordered his security forces to go after those he termed "criminals," influenced by western conspirators to overthrow him. From that point, the uprising, which had begun peacefully, turned violent as a result of Gadhafi's brutal response to the protesters. ${ }^{31}$

An obstinate Ghaddaffi not only threatened to deal with the protestors, but called them "rats and cockroaches," while threatening to go house by house sniffing them out. In what looked like wording similar to that used in Rwanda, Bellamy and Williams argue that in words that bore resemblance to the Rwanda genocide of 1994, Ghaddaffi told the world how his security officers would deployed throughout the country to purify the surrounding towns from the cockroaches and Libyan rebels who took up arms against the regime. ${ }^{32}$ Upon hearing this, the international community passed United Nations Security Council resolution 1970 in reference to Libya in a bid to pacify the Ghaddaffi's regime. Not satisfied with the situation in Libya and, particularly regarding allegations of further clamp downs on civilians by the Ghaddaffi regime, and the plan to take over Benghazi, the United Nations Security Council passed resolution 1973, which authorized the use of every means necessary to protect civilians. Resolution 1973 began with a call for "the immediate establishment of a ceasefire." It reiterated "the responsibility of the Libyan authorities to protect the Libyan population" and reaffirmed that "parties to armed conflicts bear the primary responsibility to take all feasible steps to ensure the protection of civilians." The resolution authorized UN Member States "to take all necessary measures to protect civilians and civilian populated areas" of Libya. ${ }^{33}$

However, as Cohn points out with respect to the Libyan intervention, the military force exceeded the bounds of the "all necessary measures" authorization. ${ }^{34}$ "All necessary measures" should have first comprised peaceful measures to settle the conflict. Yet, peaceful means were not exhausted before the military invasion began. A high level international team - consisting of representatives from the Arab League, the African Union, and the UN Secretary General should have been dispatched to Tripoli in an attempt to negotiate a real cease-fire, and establish a mechanism for elections and for protecting civilians. Moreover, after the passage of the resolution, Libya immediately offered to accept international monitors and Ghaddaffi offered to step down and leave Libya, but the demonization of Ghaddaffi meant the offers were immediately rejected by the opposition and the international community.

Ultimately, the North Atlantic Treaty Organisation (NATO) led intervention not only threw up emerging challenges for the RtoP doctrine, the ousting and eventual killing of Ghaddaffi led to more criticism of the doctrine. The RtoP consensus underpinning Resolution 1973 was damaged by gaps in expectation, communication, and accountability between those who mandated the operation and those who executed it. ${ }^{35}$ Indeed, the effects of the Libya intervention continue to act as a barrier to the future application of RtoP especially in Syria where millions of civilians have been killed.

\footnotetext{
${ }^{30}$ S. Awan, "The Libya Conspiracy: A Definitive Guide to the Lies of the Libya 'Intervention' and the Crime of the Century," interview by William Ramsey, William Ramsey Investigates, January 28, 2017, accessed January 18, 2019, https://www.youtube.com/watch?v=gCySEiOdUEk.

${ }^{31}$ Alex J. Bellamy and Paul D. Williams, “The New Politics of Protection: Cote d'Ivoire, Libya and the Responsibility to Protect," International Affairs 87, no. 4 (2011), 838. DOI: 10.1111/j.1468-2346.2011.01006.x

${ }^{32}$ Ibid., 838.

${ }^{33}$ United Nations Security Council, Resolution 1973, adopted March 17, 2011, (UN Doc. S/RES/1973), accessed December 15, 2018, https://www.securitycouncilreport.org/atf/cf/\%7B65BFCF9B-6D27-4E9C-8CD3-CF6E4FF96FF9\%7D/Libya S RES 1973.pdf.

${ }^{34}$ Marjorie Cohn, “The Responsibility to Protect - The Cases of Libya and Ivory Coast," Global Research: Centre for Research on Globalization (May 2011), accessed March 22, 2017, http://www.globalresearch.ca/the-responsibility-toprotect-the-cases-of-libya-and-ivory-coast/24799.

${ }^{35}$ Thakur, Emerging Powers, 4.
} 


\section{Post Election Crisis in Cote d'Ivoire}

Ethnic and political tensions in Cote d'Ivoire facilitated the outbreak of electoral violence between the period 2010- 2011, posing a risk to populations throughout the country. The conflict in Cote d'Ivoire emerged due to the disputed results of a long postponed presidential election on November 28, 2010. As a result, there were clashes between the supporters of the incumbent President, Laurent Gbagbo, and the main opposition candidate, Alassane Quattara. Within days of Gbagbo claiming victory, there was a heavy military crackdown on civilians by security forces loyal to Gbagbo, leading to the death of several. This prompted the Economic Community of West African States (ECOWAS) and the United Nations Secretary General to call for external actions to halt the senseless killings. ${ }^{36}$ Increasing violence in the country led to a series of Security Council resolutions, with resolution 1975 authorizing the use of all necessary means to protect civilians. ${ }^{37}$ The RtoP experiment in Libya supported the Cote d' Ivoire scenario. Resolution 1975 can be viewed in tandem with resolution 1973 in Libya. Both Security Council resolutions undoubtedly represents the international community's willingness to authorize the use of force to protect civilians from war crimes, crimes against humanity, ethnic cleansing, and genocide, while also affirming the role of the national state to protect its citizens. ${ }^{38}$ Though the intervention remains timely, and to a large extent helped to avert further atrocities against civilians, it again raises the question about if RtoP should be used as a cover for regime change.

\section{Mali and the Tuareg Rebellion of 2012}

The roots of the Mali crisis can be found in a long history of marginalization and distrust among Bamako and the various tribes in Mali. In 2011, the flight of thousands of Tuaregs from Libya following the ousting of Ghaddaffi by the NATO forces gave rise to regional fears of a new Tuareg insurgency throughout Mali, Niger, and other countries within the Sahel region. Having fled Mali after long exclusion policies of successive Malian governments, the Tuarge rebels returned to Mali after the fall of Ghaddaffi, their main benefactor. In 2011, they joined with other former rebels to form a new force, the National Movement for the Liberation of Azawad (MNLA), which claimed to be fighting for an independent state in the north. Unlike other conflicts that have taken place in Mali, the political and security crisis that erupted in 2012 undoubtedly took the world by surprise as the Tuareg rebels almost overran the entire country. Initially in early 2012, the rebellion in the north of the country was led by conventional local separatists who wanted to set up an independent state for the area's native Saharan Tuareg people. ${ }^{39}$ In early 2012, the MNLA, supported by a nascent Tuareg-led Islamist group, Ansar al Deen, embarked on a series of attacks on the Malian military outposts. The challenges of elite corruption, mismanagement, and the deepening activities of the rebels that led to the capture of major towns throughout Mali not only demoralized the Malian troops, but also undermined their support for the Toure regime. Moreover the inability of the Toure regime to address these long held grievances eventually led to several Tuareg soldiers deserting the national army and joining MNLA. ${ }^{40}$ The Islamists hoped to take control of Mali in its entirety not just the Tuareg north - and transform the country into a Islamic state. This internal crisis led to food shortage and greater insecurity in Mali and her neighboring countries.

Even though the crisis in Mali did not witness the urgent response such a conflict would herald, evidence abounds to suggest that both regional organizations and neighboring states responded in varying ways. Prominent among those who intervened was ECOWAS, which showed keen

\footnotetext{
${ }^{36}$ ECOWAS, "Extraordinary Session of the Authority of Heads of State and Government on Cote d'Ivoire," December 24, 2010. Press release, no. 192/2010 (Abuja: Economic Community of West African States (ECOWAS), 2012), accessed December 10, 2018, http://news.ecowas.int/presseshow.php?nb=192\&lang=en\&annee=2010.

37 "Populations at Risk in Cote D' Ivoire," Global Centre for the Responsibility to Protect, last modified December 15, 2012, accessed March 22, 2017, http://www.globalr2p.org/regions/ca te divoire.

${ }^{38}$ Cohn, The Responsibility to Protect.

${ }^{39}$ Yonah Alexander, "Terrorism in North Africa and the Sahel in 2012: Global Research and Implications," (Arlington: International Center for Terrorism Studies, Potomac Institute for Policy Studies, February 2013), 10, accessed January 19, 2019, http://www.potomacinstitute.org/images/TerrorismNorthAfricaSahelGlobalReach.pdf.

${ }^{40}$ Alexis Arieff, "Crisis in Mali," CRS Report R42664 (Washington, DC: Congressional Research Service, January 14, 2013), 1-18, accessed January 20, 2017, https://fas.org/sgp/crs/row/R42664.pdf.
} 
interest in the worsening situation and condemned March coup in strong terms. It equally warned the military Junta of the consequences of not returning power to civilians, while also urging the MNLA rebel groups to lay down their arms without delay. Not satisfied with the process toward ensuring peace and stability returned to the country, ECOWAS further embarked on a series of steps aimed at persuading the various actors in the Mali conflict to work for peace. These included: economic and diplomatic sanctions, encouraging its members to close their borders to Mali. It was expected that these initiatives would force Mali to engage in a comprehensive peace process. ECOWAS, thus, choose not shut its door to a possible political solution to resolving the crisis. President Blaise Compaoré of Burkina Faso was selected as lead negotiator and an agreement was reached in April 2012 outlining a transition to civilian government under an interim president, parliamentary speaker, Dioncounda Traoré. ${ }^{41}$ ECOWAS was not alone in this intervention. The UN Security Council adopted a series of resolutions to bolster this intervention: Resolutions 2056 (July 2012), 2071 (October 2012), and 2085 (December 2012). In resolution 2071, the Security Council declared its readiness to respond to the Mali crisis through a request for an international military force to assist the Malian army in recovering the key rebel held cities in the north. Consequently, the Security Council authorized the deployment of the proposed African-led International Support Mission to Mali (AFISMA) for an initial period of one year in Resolution 2085. Thereafter, it also called on its member states to effectively contribute troops to the international force and on regional and international organizations to provide training, equipment, and other logistical support to Mali.

\section{Emerging Challenges of the Practice of the Responsibility to Protect in Africa}

While the application of RtoP in Africa might have been hailed in some quarters to have saved civilians from "imminent attack," particularly in Benghazi, the practice has, however, thrown up some challenges. These challenges have manifested themselves both in the decision-making and intervention processes and post-intervention periods. Evidently, while RtoP remains a noble idea that - at face value -seeks to protect civilians, its practice in a host of Africa countries has shown the doctrine tends to compound the problems it was designed to solve. The most counterintuitive aspect of RtoP is that it has contributes to the tragedies it intends to prevent. For instance, in spite of the international community assurances in Libya, the country is worse off today. As is evidently the case, neither the removal and nor the eventual killing of Ghaddaffi restored peace in Libya. The country is now largely characterized by social banditry, insurgency, sectionalism, and an almost total absence of a central authority. ${ }^{42}$ Libya is not alone in this characterization. Mali has also shown how deeply flawed external interventions can end. Today, the insurgency has increased tremendously with great consequences for people of Mali and its neighbors.

Even though mediation and prevention remain central to the RtoP doctrine, these instances suggest the aforementioned were not adequately employed. There is little doubt there has been a concentration on Pillar III- the use of force- by intervening states. This has ultimately led to the misuse, misapplication, and misinterpretation of security resolutions, particularly in Libya and Mali. A careful reading of the UN Security Council Resolution 1973 in Libya underscores how the use of force or eternal intervention was never explicit. Rather, it reminded the Libyan authorities of its duty to protect its citizens. For Loiselle and Morris, the most fundamental concern with UN Security Council resolution 1973 was the inclusion of only a suggestion of Pillar I of RtoP, and this was strictly about the responsibility of the Libyan state to protect its citizens from war crimes, genocide, crimes against humanity and ethnic cleansing. ${ }^{43}$ Furthermore, Loiselle critically observes that the mere mentioning of the international community, as demonstrated in resolution 1973, does not in any way constitute an Opinio juris giving approval to the duty or role of the international

\footnotetext{
${ }^{41}$ ECOWAS, Final Communiqué, Extraordinary Summit of ECOWAS Heads of State and Government, Abuja, Nigeria, March 27, 2012. No. 083/2012, accessed January 22, 2017, http://news.ecowas.int/presseshow. php?nb=083\&lang=en\&annee $=2012$.

${ }^{42}$ Kuperman, Rethinking, 22.

${ }^{43}$ Maria-Eve Loiselle, "The Normative Status of the Responsibility to Protect After Libya," Global Responsibility to Protect 5, no. 3 (2013), 341.
} 
community within the ambits of customary international law. ${ }^{44}$ Also, an African led mission was proposed for the intervention in Mali, however, as events turned out, the French led intervention held sway with the international community.

Furthermore, even though some scholars like Arbour, Welsh and Banda, ${ }^{45}$ have argued RtoP enjoys customary appeals, which grounds it in international law, the continuous condemnation and rejection of the doctrine shows that far from this being the case, RtoP is yet to be accommodated within international law. The subjective evaluation of humanitarian crises without any clear criterion has been established in international law, the subjective decision making on the type of human action to be adopted, and, in the worst case, unauthorized humanitarian intervention remains irreconcilable with the foundations of international law. Not only that, RtoP is still far from being rooted in international law. The way and manner in which interventions have been carried out without due regard for the basic rules of engagement also remains an outrage to international law. Interestingly, the four crimes - genocide, war crimes, crimes against humanity, and ethnic cleansing- all of which are grounds the international community can use to authorize international action, have remained fluid and ambiguous. More so, RtoP -far from being a protective framework- has rather focused so much on civil conflicts without paying attention to other humanitarian challenges such as famine and poverty that also threaten human life. This has led to further criticisms of RtoP. For Shin-Wha, the problem of RtoP relates to its heavy emphasis on the protection of civilians in situations of violent conflict and its failure to properly address crises induced by extreme poverty and famine. ${ }^{46}$

At the decision-making level, RtoP has been confronted with the question of who has the authority to intervene and how should the intervention be carried out. Specifically, in the wake of the Libya crisis, the immediate problem that arose was not a problem of intervention, but rather how and who had the duty to intervene. This was made worse by the fact that the RtoP doctrine was not affirmative in terms of placing such a duty at the doorstep of a state; neither has the doctrine been able to resolve the ambiguity of RtoP as it concerns the four crimes upon which an intervention can be justified. Rather, the doctrine employs the term "international community" as those who can intervene should states fail to protect their citizens. The problem of who has the authority to intervene lingers from the cases of Libya, Mali, and Côté d'Ivoire, among others that are ongoing. In addition, though RtoP places regional organizations in a better position to carry out interventions, visible evidence suggests, at best, these regional bodies continue to play a mere gatekeeping role. Also, regional bodies, such as the Africa Union (AU) and the Economic Community of West Africa States (ECOWAS) have not lived up to expectations in terms of responding promptly to conflict situations. For instance, in Libya, the AU was deeply divided on how to respond, while in Mali, the response to the conflict was largely incoherent and haphazard. This ultimately led to setting aside an Africa led mission in favor of an internationally organized mission. The controversy surrounding the question of authority has remained one with no resolution in sight. Yet, more and more interventions have continued to be sanctioned by the United Nations Security Council with Africa nations playing little or no role in making vital decisions on issues around the continent. The absence of a unified method of arriving at how to apply the doctrine has led to misconceptions and the misinterpretation of various UN Security Council resolutions, especially in Libya.

Reflecting on the conceptual ambiguity that has surrounded RtoP, Edward Luck argues that nine years after the doctrine was initiated by the International Commission for Intervention and State Sovereignty (ICISS), and five years after it was unanimously adopted in a World Summit Document of 2005, emerging issues such as; whether, where and how the RtoP has fared. ${ }^{47}$ Though he admits these emerging challenges emanate mainly from scholars who are unconvinced by the

\footnotetext{
${ }^{44}$ Ibid., 341.

${ }^{45}$ Arbour, Duty Care, 445; Jennifer M. Welsh \& Maria Banda, "International Law and the Responsibility to Protect: Clarifying or Expanding States' Responsibilities?,"Global Responsibility to Protect 2, no. 2 (2010), 230.

${ }^{46}$ Lee Shin-Wha, "The Responsibility to Protect (RtoP) in Humanitarian Emergencies: From Libya to North Korea?," Asia Security Initiative, working paper no. 22 (Seoul: East Asia Institute, 2012), 13.

${ }^{47}$ Edward Luck, “The Responsibility to Protect: Growing Pains or Early Promise?," Ethics and International Affairs 24, no. 4 (December 2010), 356.
} 
RtoP doctrine, Luck suggests RtoP is yet to demonstrate it possesses the ability to protect civilians from atrocity crimes. ${ }^{48}$ For this reason, Luck goes on to provide four caveats about the RtoP doctrine that remain fundamental: (1) it is be too early to makes assumptions about the future of RtoP, (2) the doctrine is still evolving, which means that some of the conceptual and operational challenges are still being considered by member states, (3) it is important to distinguish between RtoP as principle and RtoP as a guide, and (4) comparative case are essential to evaluate RtoP. Luck concludes there is need to avoid the conventional thinking of critics who once predicted a bleak future for human rights. ${ }^{49}$

Furthermore, in spite of assurances from World leaders as to the differentiation between RtoP and humanitarian intervention, the way in which RtoP has been applied, as an interventionist framework in armed conflict situations, suggests the doctrine remains nothing but a mere change in nomenclature. This has been made worse by the fact that while intervening states acknowledge the various principles enshrined in RtoP continue to place an emphasis on direct military action. For Stahn, even though RtoP may gradually replace the doctrine of humanitarian intervention, at present, many of the propositions as well as the practice of the concept remains largely uncertain from a normative point of view. ${ }^{50}$ The RtoP doctrine is, thus, in many ways still a political catchword rather than a legal norm, which will need further fine-tuning and commitment from states for it to develop into an organizing principle for international society. Particularly, even though resolution 1970 passed, the international community did not allow the resolution to see the day of light before resolution 1973, which was used as a justification for the Libyan intervention. This was made possible through the demonization of Ghaddaffi. It is, therefore, not surprising Ghaddaffi's offer of a ceasefire was not given any real consideration.

More importantly, the apparent and the unending question of when intervention is necessary, or how many civilians must be killed to provoke intervention, how do we quantify rights that are violated warranting external intervention, have remained a difficult task for the RtoP doctrine to achieve. Fascinatingly, since states have within their residual powers the ability to quell internal rebellion using a minimal level of force, the puzzling question of when, therefore, remains more controversial. Thus, the question that requires clarification at what point or how we measure the justification for intervention within the context of quelling internal rebellion to uphold law and fundamental rights. Looking at the nature of the protests and the characters involved in the Libya uprising, it would be difficult to arrive at the conclusion that those civilians Ghaddaffi clamped down on were helpless civilians. There was nothing about the situation in Libya that bared resemblance to civilians organizing mass protests given that none of the locations where the protests took place where typical protest locations in Libya. Instead, these confrontations took place at police stations, security offices, or military barracks, resulting in the taking of large amounts of weaponry. ${ }^{51}$ Hence, while it could be successfully argued that Ghaddaffi threatened to kill those protesting against him, what remains unclear is the existence of evidence suggesting an imminent massacre in Benghazi, which led to UN Security Council Resolution 1973. It must equally be observed that Libya is not alone in this problem, just as the case of Syria becomes more complicated with every passing year of conflict. In fact, the nature of the protests from their onset to date assumed a violent dimension and this accounted for the brutal response from the Assad regime. Hence, what was initially termed a public protest has gradually snowballed into a civil conflict. This has, therefore, created a dilemma for the international community regarding how to respond, if at all.

\footnotetext{
${ }^{48}$ Luck, Growing Pains or Early Promise?, 366.

${ }^{49}$ Edward Luck, "The Responsibility to Protect: The First Decade, Global Responsibility to Protect," Global Responsibility to Protect 3, no. 4 (2011), 388-391.

${ }^{50}$ Carsten Stahn, "Responsibility to Protect: Political Rhetoric or Emerging Legal Norm?," The American Journal of International Law 101, no. 1 (2007), 120.

${ }^{51}$ Awan, The Libya Conspiracy.
} 


\section{Prospects for the Responsibility to Protect in Africa}

Admittedly, the practice of RtoP in Africa has remained controversial and largely counterproductive. Yet, the need to protect civilians in conflict situations remains. This underscores the need to reevaluate the emerging challenges confronting the doctrine with a view of correcting the emerging challenges associated with its practice. Undoubtedly, the question of framing RtoP, as a concept and a human rights framework for the prevention of atrocity crimes, is long overdue and, particularly if the doctrine is to remain relevant for the protection of civilians. There is a need to situate RtoP properly within in the context of situations in which the doctrine is applied and vice versa. More specifically, the doctrine needs to extend to those humanitarian catastrophes that are not prevalent in political discourse. The act of framing the doctrine opens ground for shared space, as is becoming the generally accepted framework for responding to the protracted conflict and crimes against humanity. ${ }^{52}$

Secondly, if RtoP is to live up to its expectations, intervening countries must reassure the world that genuine step towards avoiding the past mistakes of Rwanda and Kosovo are being taken. While Libya suggests the international community was prompted to avoid such mistakes, similar conflict situations have proved otherwise. In other words, it is safe to argue the national interest of intervening states continues to influence their decisions to intervene in conflicts. Conflicts on the African continent in the wake of the Libyan crises as well as the long-protracted conflicts in Syria underscore that RtoP continues to be entangled; caught between responding to humanitarian needs and national interest. The international community must begin to demonstrate a real commitment towards addressing this problem through establishing or strengthening existing security frameworks such as early warning mechanisms, a panel of the wise, and the United Nations General Assembly to draw the attention of world leaders to cases of humanitarian catastrophe as well as how to respond.

Another area upon which the doctrine of RtoP could be improved is through critical reflection on the idea of "responsibility while protecting" (RWP), as championed by Brazil. The idea behind this concept is that, even if military intervention is a last resort, then those countries that intervene militarily under the doctrine of the RtoP should exercise proportionality and balance the consequences of their external interventions. This has become imperative, especially given the backlash in the wake of the Libyan intervention. Even though the guiding principles for intervention put forth by ICISS specify some of these criteria, adequate attention have not been paid to them and this has brought about post intervention challenges such as acute challenges associated with rebuilding. Specifically, there is a need to rethink, if not reconceptualize, the question of last resort in connection with external intervention and, particularly in light of prevention remaining vital to RtoP. The extent to which diplomacy, negotiations, and political settlement should be applied to conflicts in Africa must be purposeful.

Since the adoption of RtoP, civil society organizations have struggled with some important issues surrounding RtoP. They are concerned about the advantages, the disadvantages, and abuse of the doctrine. This has not only influenced the internalization of the doctrine, it has equally led to varied interpretations of UNSC mandates and implementation processes. More often, civil society organizations have only focused on the state under international scrutiny, while paying little attention to international actors and, particularly those intervening states. For instance, while civil society organizations played a crucial role in calling for intervention in Libya, they have, however, been mute on the question of the responsibility to rebuild societies where intervention has taken place. Positively, civil society needs to increase the rate at which they engage both with international and national governments, international and regional organizations, the media, and other relevant stakeholders to reach of the objectives of the duty to protect.

Evidently, from the application of RtoP in places such as Libya, Mali, and Côté d'Ivoire, intervening countries have - over time - continued to show a preference for military options despite prevention remaining key to RtoP. Preference must be given to non-military methods such as peace building, preventive diplomacy, mediation, referring cases to the international criminal court and

${ }^{52}$ Christof Royer, "Framing and Reframing R2P - a Responsibility to Protect Humanity From Evil," Critical Review of International Social and Political Philosophy, (2018), 3. DOI: 10.1080/13698230.2018.1479818 
the Africa court of human rights, the use of respected envoys, implementing convincing sanctions, as well as the condemnation of atrocities by international organizations, regional organizations, along with human right bodies and the media. The RtoP toolbox consists of instruments that, depending on the local context, non-sequentially, but often simultaneously contribute to the prevention of mass atrocities, the protection of civilians during ongoing conflict, and the stabilization of countries emerging from conflict. Structural tools to prevent react, or rebuild include the promotion of membership in international organizations, support of equitable development, and security sector reform; examples of direct tools are preventive diplomacy, criminal prosecution, and humanitarian engagement. ${ }^{53}$

In summary, though the application of RtoP has exposed challenges, opportunities abound for the doctrine in Africa and a host of other countries where human rights violations and crimes against humanity continue to take their toll. While it could be argued the application of RtoP, at present, remains divided among states and actors in the Global North and Global South, they do unanimously attest to the reality that crimes against humanity should not be tolerated in any manner. This was demonstrated by ECOWAS involvement in the Gambia issue and the continuous condemnation of the Syria crisis, even though the world has yet to take proactive steps towards civilian protection in Syria. In essence, while the application of RtoP in a host of African countries, as demonstrated in this study, has exposed some fundamental challenges with the doctrine, it should, however, not deter the international community from its future application. Wellmonitored RtoP application in terms of the use of diplomacy, envoys, sanctions, regional solutions, political solutions, and judicial inquiries should all be encouraged. And, in the event of the use of Pillar III of RtoP, such intervention must be monitored strictly, just as intervening states must also commit themselves to the dictates of the doctrine, the local dynamics of the conflict as well as well as engaging locals in resolving their conflicts is essential.

\section{Acknowledgements}

I would like to acknowledge Wale Adeboye, Emmanuel Remi Aiyede, and Laura Collins for their insightful comments and efforts.

\section{Bibliography}

Alexander, Yonah. "Terrorism in North Africa and the Sahel in 2012: Global Research and Implications." Arlington: International Center for Terrorism Studies, Potomac Institute for Policy Studies, February 2013, 1-31. Accessed January 19, 2019. http://www. potomacinstitute.org/images/TerrorismNorthAfricaSahelGlobalReach.pdf.

Arbour, Louise. "The Responsibility to Protect as a Duty Care in International Law and Practice," Review of International Studies 34, no. 3 (2008), 445-458. DOI: 10.1017/S0260210508008115

Arieff, Alexis. "Crisis in Mali." CRS Report R42664. Washington, DC: Congressional Research Service. January 14, 2013. Accessed January 20, 2017. fas.org/sgp/crs/row/R42664.pdf.

Awan, S. "The Libya Conspiracy: A Definitive Guide to the Lies of the Libya 'Intervention' and the Crime of the Century." Interview by William Ramsey. William Ramsey Investigates, January 28, 2017. Accessed January 18, 2019. https://www.youtube.com/watch?v=gCySEiOdUEk.

Barnett, Michael. Empire of Humanity: A History of Humanitarianism. Ithaca: Cornell University Press, 2011.

Bellamy, Alex J. and Paul D. Williams. “The New Politics of Protection: Cote d'Ivoire, Libya and the Responsibility to Protect," International Affairs 87, no. 4 (2011), 825-850. DOI: 10.1111/j.14682346.2011.01006.x

Bellamy, Alex J. and Nicholas J. Wheeler. "Humanitarian Intervention in World Politics." In The Globalisation of World Politics: An Introduction to International Relations, edited by John Baylis, Steve Smith and Patricia Owens, 510-527. Oxford: Oxford University Press, 2008.

Bellamy, Alex J. Global Politics and the Responsibility to Protect: from Words to Deeds. Abingdon: Routledge, 2011.

\footnotetext{
${ }^{53}$ Abiodun Williams, "The Responsibility to Protect and Peacemaking," in The R2P: Challenges and Opportunities in Light of the Libyan Intervention, ed. Thomas G. Weiss et al. (E-International Relations, August 2011), 31-33, accessed January 18, 2019, https://www.e-ir.info/publication/the-r2p-challenges-and-opportunities-in-light-of-the-libyan-intervention.
} 
--------. “The Responsibility to Protect - Five Years On." Ethics \& International Affairs 24, no. 2 (2010), 143-169.

Branch, Adam. "The Irresponsibility of the Responsibility to Protect in Africa." In Critical Perspectives on the Responsibility to Protect: Interrogating Theory and Practice, edited by Philip Cunliffe, 103-125. New York, Routledge, 2011. DOI: 10.4324/9780203834299

Carmen, Cristina C. "Protecting Civilians in Armed Conflict: International Framework and Challenges." European Parliamentary Research Service (EPRS) Briefing, 2016. Accessed January 12, 2017. http://www.europarl.europa.eu/thinktank/en/document. html?reference=EPRS BRI(2016) 573917.

Chandler, David. "The Responsibility to Protect? Imposing the Liberal Peace." International Peacekeeping 11, no. 1 (2004), 59-81. DOI: 10.1080/1353331042000228454

Cohn, Marjorie. "The Responsibility to Protect - The Cases of Libya and Ivory Coast." Global Research: Centre for Research on Globalization, May 2011. Accessed March 22, 2017. https://www.globalresearch.ca/the-responsibility-to-protect-the-cases-of-libya-and-ivorycoast $/ 24799$.

Dembinski, Matthias and Theresa Reinold. "Libya and the Future of the Responsibility to Protect - African and European Perspectives." PRIF, report no. 107. Frankfurt: Peace Research Institute Frankfurt, 2011. Accessed January 18, 2019. http://www.hsfk.de/fileadmin/HSFK/ hsfk downloads/prif107.pdf.

Deng, Francis M., Sadikel Kimaro, Terrence Lyons, Donald Rothchild, and I. William Zartman, eds. Sovereignty as Responsibility: Conflict Management in Africa. Washington, DC: Brookings Institution Press, 2010.

ECOWAS. "Extraordinary Session of the Authority of Heads of State and Government on Cote d'Ivoire." December 24, 2010. Press release, no. 192/2010. Abuja: Economic Community of West African States, 2012. Accessed December 10, 2018. http://news.ecowas.int/presseshow. php?nb=192\&lang=en\&annee=2010. DOI: 10.1007/978-1-349-58635-6 67

--------. Final Communiqué. Extraordinary Summit of ECOWAS Heads of State and Government. Abuja, Nigeria, March 27, 2012. No. 083/2012. Accessed January 22, 2017. http://news. ecowas.int/presseshow.php?nb=083\&lang=en\&annee=2012.

Evans, Gareth and Mohammed Sahnoun. "The Responsibility to Protect." Foreign Affairs 81, no. 6 (Nov - Dec 2002), 99-110. DOI: 10.2307/20033347

Evans, Gareth. "From Humanitarian Intervention to Responsibility to Protect." Wisconsin International Law Journal 24, no. 3 (2006), 704-722.

-. "The Consequences of Syria: Does the Responsibility to Protect have a future?" E-International Relations, 2014. Accessed January 18, 2019. https://www.e-ir.info/2014/01/27/ the-consequences-of-non-intervention-in-syria-does-the-responsibility-to-protect-have-afuture/.

"The Responsibility to Protect: An Idea Whose Time Has Come and Gone." International Relations 22, no. 3 (2008), 283-298. DOI: 10.1177/0047117808094173

. "Implementing the Responsibility to Protect: Lessons and Challenges." Alice Tay Lecture on Law and Human Rights, Australian National University, Canberra, Australia, May 5, 2011. Accessed January 12, 2017. http://www.gevans.org/speeches/speech437.html.

Finnemore, Martha. The Purpose of Intervention: Changing Beliefs about the Use of Force. Ithaca: Cornell University Press, 2003.

Francioni, Francesco and Christine Bakker. "Responsibility to Protect, Humanitarian Intervention and Human Rights: Lessons from Libya to Mali." Transworld, working paper no. 15 (April 2013). Accessed January 18, 2019. http://www.iai.it/sites/default/files/TW WP 15.pdf.

Global Centre for the Responsibility to Protect. "Populations at Risk in Cote D' Ivoire." Last modified December 15, 2012. Accessed March 22, 2017. http://www.globalr2p.org/regions/ ca te divoire.

Irvin-Erickson, Douglas. "Protection from Whom? Tensions, Contradictions, and Potential in the Responsibility to Protect." In Rethinking Security in the Twenty-First Century, edited by Edwin Daniel Jacobs, 105-124. London: Palgrave, 2016.

DOI: $10.1057 / 978-1-137-52542-0 \quad 8$ 
Kaldor, Mary. New and Old Wars: Organised Violence in a Global Era, 3rd ed. Cambridge, UK: Polity Press, 2012.

Kuperman, Alan J. "False Pretense for war in Libya?" The Boston Globe, April 14, 2011. Accessed January 12, 2017. http://archive.boston.com/bostonglobe/editorial opinion/oped/ articles/2011/04/14/false pretense for war in libya/.

--------. "Rethinking the Responsibility to Protect." The Whitehead Journal of Diplomacy and International Relations 33, no. 4 (2009), 19-29.

Loiselle, Maria-Eve. "The Normative Status of the Responsibility to Protect after Libya." Global Responsibility to Protect 5, no. 3 (2013), 317-341.

Luck, Edward. "The Responsibility to Protect: Growing Pains or Early Promise?" Ethics and International Affairs 24, no. 4(December 2010), 349-365. DOI: 10.1111/j.1747-7093.2010.00276.x "The Responsibility to Protect: The First Decade, Global Responsibility to Protect." Global Responsibility to Protect 3, no. 4 (2011), 387-399.

Mahmood, Mamdani. Saviors and Survivors: Darfur, Politics, and the War on Terror. New York: Pantheon, 2009.

Murithi, Tim. "The Responsibility to Protect, as Enshrined in Article 4 of the Constitutive Act of the African Union," African Security Review 16, no. 3 (September 2007), 14-24. DOI: 10.1080/10246029.2007.9627428

Nauruzzmaan, Mohammed. “The 'Responsibility to Protect Doctrine: Retrieved in Libya, Buried in Syria." Insight Turkey 15, no. 2 (2013).

Orford, Anne. Reading Humanitarian Intervention: Human Rights and the Use of Force in International Law. Cambridge, UK: Cambridge University Press, 2003.

Paris, Roland. "The 'Responsibility to Protect' and the Structural Problems of Preventive Humanitarian Intervention." International Peacekeeping 21, no. 5 (October 2014), 569-603. DOI: $10.1080 / 13533312.2014 .963322$

Pattison, James. Humanitarian Intervention and the Responsibility to Protect: Who Should Intervene. Oxford: Oxford University Press, 2010. DOI: 10.1093/acprof:oso/9780199561049.003.0001

Puley, Greg. "The Responsibility to Protect: East, West, and Southern African Perspectives on Preventing and Responding to Humanitarian Crises." Working Paper 05-5. Ontario: Africa Peace Forum, African Women's Development and Communication Network, Africa Institute of South Africa, and Project Ploughshares, 2005. Accessed January 18, 2019. http:// www.responsibility toprotect.org/files/ploughshares.pdf.

Sarkin, Jeremy. "The Responsibility to Protect and Humanitarian Intervention in Africa." Global Responsibility to Protect 2, no. 4 (2010), 371-387. DOI: 10.1163/187598410X519543

Shin-Wha, Lee. "The Responsibility to Protect (RtoP) in Humanitarian Emergencies: From Libya to North Korea?" Asia Security Initiative, Working paper no. 22. Seoul: East Asia Institute, 2012.

Stahn, Carsten. "Responsibility to Protect: Political Rhetoric or Emerging Legal Norm?" The American Journal of International Law 101, no. 1 (2007), 99-120. DOI: 10.1017/S0002930000029559

Royer, Christof. "Framing and Reframing R2P - A Responsibility to Protect Humanity from Evil." Critical Review of International Social and Political Philosophy (2018), 1-25. DOI: 10.1080/13698230.2018.1479818

Teson, Fernando. "The Liberal Case for Humanitarian Intervention." In Humanitarian Intervention: Ethical, Legal and Political Dilemmas, edited by Jeff L. Holzgrefe and Robert O. Keohane, 93-129. Cambridge, UK: Cambridge University Press, 2003. DOI: 10.1017/ CBO9780511494000.004

Thakur, Ramesh. "Emerging Powers and the Responsibility to Protect after Libya." NUPI, policy brief no. 15. Oslo: Norwegian Institute of International Affairs, January 2012, 1-4. Accessed December 18, 2018. https://brage.bibsys.no/xmlui/handle/11250/224065.

. "Libya and the Responsibility to Protect: Between Opportunistic Humanitarianism and Value-Free Pragmatism." Security Challenges 7, no. 4 (2011), 13-25.

United Nations Security Council. Resolution 1973. Adopted March 17, 2011. UN Doc. S/RES/1973 (2011). Accessed December 15, 2018. https://www.securitycouncilreport.org/atf/ cf/\%7B65BFCF9B-6D27-4E9C-8CD3-CF6E4FF96FF9\%7D/Libya S RES 1973.pdf. 
Wai, Zubarui. “The Empire's New Clothes: Africa, Liberal Interventionism and Contemporary World Order." Review of African Political Economy 41, no. 142 (September 2014), 483-499. DOI: $10.1080 / 03056244.2014 .928278$

Weiss, Thomas G. "R2P After 9/11 and the World Summit." Symposium on Humanitarian Intervention After 9/11. Wisconsin International Law Journal 24, no 3 (2006), 741-760.

Welsh, Jennifer M. and Maria Banda. "International Law and the Responsibility to Protect: Clarifying or Expanding States' Responsibilities?" Global Responsibility to Protect 2, no. 2 (2010), 213-231. DOI: 10.1163/187598410X500363

Wheeler, Nicholas J. Savings Strangers: Humanitarian Intervention in International Society. Oxford: Oxford University, 2008.

Williams, Abiodun. "The Responsibility to Protect and Peace Making." In The R2P: Challenges and Opportunities in the Light of the Libyan Intervention, edited by Thomas G. Weiss, Ramesh Thakur, Mary Ellen O' Connell, Aidan Hehir, Alex J. Bellamy, David Chandler, Rodger Shanahan, Rachel Gerber, Abiodun William and Gareth Evans. E-International Relations, 2011, 31-33. Accessed January 18, 2019. https://www.e-ir.info/publication/the-r2pchallenges-and-opportunities-in-light-of-the-libyan-intervention/.

Williams, Paul D. "Enhancing Civilian Protection in Peace Operations: Insights from Africa." Africa Center for Strategic Studies, Research paper no. 1. Washington, DC: National Defense University Press, 2010.

Zifcak, Spencer. "The Responsibility to Protect after Libya and Syria." Melbourne Journal of International Law 13, no. 1 (2012), 1-35. 